KREŠIMIR VIDOVIĆ, Ph.D. ${ }^{1}$

(Corresponding author)

E-mail: kresimir.vidovic@ericsson.com

MARKO ŠOŠTARIĆ, Ph.D. ${ }^{2}$

E-mail: marko.sostaric@fpz.hr

DAMIR BUDIMIR, Ph.D. ${ }^{2}$

E-mail: damir.budimir@fpz.hr

${ }^{1}$ Ericsson Nikola Tesla

Krapinska 45, 10000 Zagreb, Croatia

2 Faculty of Transport and Traffic Sciences,

University of Zagreb

Vukelićeva 4, 10000 Zagreb, Croatia
Traffic and Space

Review

Submitted: 3 June 2019

Accepted: 1 Oct. 2019

\title{
AN OVERVIEW OF INDICATORS AND INDICES USED FOR URBAN MOBILITY ASSESSMENT
}

\begin{abstract}
The urban mobility is affected by global trends resulting in a growing passenger and freight transport demand. In order to improve the understanding of urban mobility in general, to evaluate mobility services and to quantify the overall transport system performance, it is necessary to assess urban mobility. Urban mobility assessment requires the application of methodology integrating different metrics and explicitly applying a multi-dimensional approach. Since scientific community does not define urban mobility in an unambiguous way, part of this paper is devoted to the analysis of the definition of urban mobility. This step enables better understanding of urban mobility in general, as well as understanding of the urban mobility assessment process. Usually, a three-layered approach that includes urban mobility data, indicators and indices is used for the assessment. Therefore, the aim of this paper was to perform extensive research in order to synthesize, define and organize the elements of those layers. The existing urban mobility indicators and indices have been developed for specific urban areas, taking into account local specifications, and they are not applicable in other cities. Also, the choice of urban mobility indicators is mainly related to the existence of data sources, which limits the objective and comparable assessment of the mobility of cities where such data do not exist.
\end{abstract}

\section{KEY WORDS}

transport; urban mobility; assessment; ecology; society; economy indicators; indices; Intelligent Transport Systems (ITS);

\section{INTRODUCTION}

The definition of basic urban mobility states that mobility in the urban environment represents movements with the goal of accessing the desired destinations by using different transport modes [1]. The mobility encompasses the movement with an objective to access the desired destinations by the utilisation of different transport modes. The purpose of mobility is to ensure accessibility to the desired destinations by using various travelling modes.

Urban mobility needs to be assessed in order to identify key or critical elements of the transport system and to identify its weaknesses and strengths. The assessment provides insight into the state of urban mobility and creates a foundation for the improvement of the existing and the creation of new services in the Intelligent Transport Systems (ITS) area.

Urban mobility assessment is based on urban mobility data, indicators and indices. The urban mobility data are heterogeneous and collected by using various sources, which are available at the designated area for which the mobility assessment is performed. According to the data availability, urban mobility indicators are defined. Urban mobility indicator is the value based on data from the segment of the urban mobility which describes the phenomena that affect urban mobility, or is the result of urban mobility.

Since there might be a large number of urban mobility indicators, in order to reduce the complexity and scope of data and indicators to be included in the urban mobility assessment, the urban mobility index is introduced. Urban mobility index is, therefore, a single numerical mobility assessment score, as a result of the relational data and/or mobility indicators fusion.

The aim of this paper was to present an overview of the literature on three-layered urban mobility assessment, with detailed analysis of each layer. Extensive research was performed in order to synthesize, define and organise urban mobility data, indicators and indices used in urban mobility assessment process. The paper will also try to answer the question if there was an urban mobility assessment process which can be used as a universal tool applicable to all urban agglomerations with different sizes, population, user habits, transport modes availability and other local specifics. 


\section{DEFINITION OF URBAN MOBILITY}

There are several aspects through which the mobility is being studied by the scientific community. Basic and generalised urban mobility definition states that mobility in the urban environment represents movements with the goal of accessing the desired destinations by using different transport modes [1] Urban mobility represents the movement of persons between various origins and destinations, within different time frames, by different transport means and travel modes, for the purpose of reaching divergent objectives [2]. Passenger movement can be categorised according to its purpose, travel time distribution, modal choice, movement length or other spatial features of passenger mobility. According to their purpose, the urban movements can be described as obligatory and voluntary. Obligatory trips include pendular trips, professional trips and distribution trips. Voluntary trips are usually of a personal character. Those include trips towards the points of commercial activity, cultural events and recreation or tourism-related trips (historical tourism, sport tourism or similar) [2, 3].

In terms of objectives of the individually undertaken activities requiring movement, trips can be characterised as trips to work and back, trips for the purpose of shopping, social activities, recreation, education, business and health-related trips [2, 3]. In terms of the time distribution of trips, there are trips during the daily peak loads (mainly trips to work and back) and trips related to shopping or social activities, occurring between the peak hours and during late afternoon or night time.

The third feature of passenger mobility is the modal choice of the passengers with the selection of an appropriate means of transport or their combinations. The trips could also be characterised according to their length. The trip length or the distance covered depends on the total population, population density, urban area surface and the existence of attractors. Finally, the spatial distribution of trips defines the mobility in correlation to the spatial urban structure and the spatial features of the transport system [2,3]. Depending on the authors and their approach within the urban mobility studies, mobility could also be defined differently. According to Gillis et al. [4], mobility includes movement and transportation of passengers and freight within the territory of the urban agglomeration. Mobility encompasses all transportation modes relevant for the urban transport (motorised and non-motorised, public and personal modes). For instance, those are: ships, helicopters, trains, light rail, underground, trolleybuses, cable cars, trams and buses, different types of cars, motorcycles, mopeds, bicycles, electric bicycles and walking. Mobility also includes all the relevant structures, starting from the decision makers to the service providers and end users. Kuhlike and Yuand use several mobility categories. They are: physical travel within the urban space (travelling for work, entertainment or some other purpose), physical movement of objects (packages, containers), imaginative travel (memories, books, movies), virtual travel (virtual atlases such as Google Earth, etc.) and communicative travel (letters, video-conferences, e-mails, etc.) [1]. According to Amaral, mobility is characterised by its side effects such as travel times, costs, and congestion since they immanently reflect on individuals' and communities' economic success, and improving urban mobility is crucial to the sustainable development of a city [5]. Casey et al. define the mobility through travel-related time and costs. Mobility increases with the shortening of the average travel time, lowering of the travel time deviations and travel costs [6]. According to Costa et al., mobility is a feature of an individual which enables travelling in space. It is limited by the dimensions of the urban space and it is also affected by the complex activities undertaken in that space. The individual characteristics of passengers, such as age, gender and income, together with the features of urban environment and availability of the transport service, can also have impact on mobility [7].

According to Brčić et al. [2, 8], the overall mobility is person-related and represents a total number of trips within the observed area, regardless of the trip purpose or chosen transportation mode. The mobility of inhabitants is frequently expressed as a number of trips per inhabitant within the observed time period. Possible concepts include: the mobility rate, total mobility length and total mobility time. Total mobility rate represents a daily number of trips per person. Total mobility length represents the number of achieved passenger kilometres per person in a unit of time. Total mobility time is a number of hours spent on travelling per person in a unit of time. Mobility is also frequently described by the number of vehicle kilometres, as a more complex indicator. Within the urban space, Brčić differentiates three types of urban mobility in terms of physical movement: public transportation, individual transportation and freight transportation. Public transportation as a mode is enabling mobility for all social groups represented in a population. Its efficacy is based on a large number of passengers transported and acceptable economic rationality. It includes sub-systems such as taxi service, paratransit, trams, buses, trolleybuses, LRT, metro, ferries, etc. The individual mobility includes any type of movement occurring as a result of personal mobility choice. The freight mobility is a product of urban population existential needs, with the city usually being a production and consumption centre.

According to Rashidy et al., there are two dimensions of urban mobility. The first is related to the user perspective and describes the possibility of moving from one point (the origin) to another (the destination) 
by using suitable transport mode(s). The second observes the mobility in infrastructural terms, defining it as the capacity of the transport system to ensure access to work, education, health services, commerce, etc., thus providing the final users with a possibility to reach their destinations by using appropriate transport mode(s) and a satisfactory service level. Rashidy defines the mobility as a measure of the transport system efficiency while connecting spatially detached locations, where the mobility is used as a key performance indicator of the transport system functionality [9]. Gudmundsson et al. clearly differentiate mobility from transport. Mobility represents a wider concept because it does not refer only to the real motion but also to the potential of moving i.e. the spatial, economical and social context of movement. Therefore, by analogy, the concept of mobility is more comprehensive than transport. Mobility is defined as a possibility and relative simplicity of accessing the desired destination, in reasonable time, with reasonable costs and by the desired transport mode(s) [10]. Litman defines mobility as a motion of passengers and goods, with the passenger or ton kilometres and the number of undertaken trips as the key dimensioning parameters. Mobility as a motion is not its own purpose but rather a means to achieve its objectives. Litman finds that every increase in the number of trips, passenger or ton kilometres and the travelling/transportation speed is a positive contribution to mobility [11-13]. Litman also defines accessibility [14], and its relationship with mobility. Accessibility refers to people's ability to reach goods, services and activities, which is the ultimate goal of most transport activities. Many factors affect accessibility, including mobility (physical movement), the quality and affordability of transport options, transport system connectivity, mobility substitutes, and land use patterns. Accessibility can be evaluated from various perspectives, including a particular group, mode, location or activity.

Kaparias et al. [15] define mobility as the key element of the transport system i.e. as the capability of the transport system to ensure access to work, recreation, commerce, the intermodal transfer points and other functions. The mobility expresses the ease of movement on a general level - within the urban agglomeration, or on the predefined routes connecting specific pairs of origins and destinations, regardless of the transport mode(s) used. Kaparias states that mobility can be described using different indicators. Key indicator is the average travel time needed to reach the destination (expressed by time units), normalised by distance and weighed by the factors depending on the objectives of the mobility assessment, as the key ones. According to the work by Abramovic et al. [16], mobility implies a median value of trips per inhabitant in a unit of time. Mobility can be determined for specific social groups, e.g. the workforce mobility or the mobility of schoolchildren and students. It is also possible to express the mobility of a population inhabiting a limited territorial scope as mobility in an urban, suburban or interurban transport. The most common units of time for which the mobility is usually being determined include a year, a month or a day, thus observing daily, monthly or annual mobility. The level of mobility is higher where the living standard and the quality of the transport system are better. Therefore, the level of mobility is rising with the level of social development. Vidović et al. [17] define the urban mobility as the individual's capacity to move within an urban space, in an organised and meaningful manner, by using the existing transport, communal, information and communication infrastructure, according to their physiological, intellectual and social-economic needs.

\subsection{Urban mobility assessment}

Galileo Galilei wrote: "Count what is countable, measure what is measurable, and what is not measurable, make measurable" [18]. In order to enable better understanding of the urban mobility, it needs to be assessed [19]. Previous approaches to the urban mobility assessment could be summarised as an application of the procedures that include mobility indicators and indices [4, 12, 20-22]. The urban mobility indicator is defined as a parameter based on the data from the segment of the mobility system (transport, economy, ecology, society or other), describing the phenomena which result from urban mobility or affect it. The urban mobility index is defined as a parameter resulting from a fusion of relational data and/or the urban mobility indicators with the objective of assessing urban mobility [23]. Generally, urban mobility is assessed in a way to primarily identify relevant urban mobility indicators, after which an urban mobility index is developed i.e. the mobility is assessed. The measurement provides certain values, used to define the indicators. By applying an appropriate methodology, the indices are set-up and used to carry out the mobility assessment. The initial step is to identify and collect data related to the urban mobility $[24,25]$.

\subsection{Related data sources and data}

The urban mobility data are heterogeneous and collected by using various sources which are divided into three groups [26]. The conventional data sources include the usual sources such as the sensors within the transport infrastructure, meteorological sensors, ecological sensors, etc. [25]. The second group of the data sources encompasses the information and communication systems owned and/or used by the urban mobility shareholders (the organisations providing public transport services, toll collection and similar). The examples of such systems include road toll collection system, smart public transport ticketing systems, 
Table 1 - The list of data sources usable for the purpose of the mobility assessment [22, 25, 26, 28-33, 38]

\begin{tabular}{||l|l|l||}
\hline \multicolumn{1}{||}{ Conventional data sources } & \multicolumn{1}{|c||}{$\begin{array}{c}\text { Information and communication } \\
\text { systems of the shareholders }\end{array}$} & \multicolumn{1}{|c||}{ Unconventional data sources } \\
\hline \hline Pneumatic road tube counters & Road tolling system & $\begin{array}{l}\text { Public mobile communication } \\
\text { networks }\end{array}$ \\
\hline Piezoelectric sensors & Parking fee collection system & Satellite photographs \\
\hline Inductive loops & Public bike sharing system & Social networks \\
\hline Radar traffic counters & Public car sharing system & Autonomous vehicles \\
\hline Infrared traffic counters & Car sharing system & Connected vehicles \\
\hline Magnetic traffic counters & Traffic accidents database & Navigation devices \\
\hline Ultrasound traffic counters & Registered vehicles database & In-vehicle computers \\
\hline Video traffic counters & Public passenger transport & \\
\hline Census & $\begin{array}{l}\text { Smart public passenger transport } \\
\text { ticketing }\end{array}$ & \\
\hline Ecological sensors & & \\
\hline Meteorological sensors & & \\
\hline Manual traffic counting & & \\
\hline Observation & & \\
\hline Surveys & & \\
\hline
\end{tabular}

CCTV surveillance system [27], and other applications [28]. The third group of data includes the so-called new data sources and the application of the relatively new technologies, whose application in the urban mobility assessment is still not widely spread (e.g. the public mobile communication networks, social networks, autonomous vehicles, intelligent transport systems) $[22,29-37]$. The primary function of the second and third group of data sources is not to collect or generate urban mobility data, but as side effect they generate data useful for the urban mobility assessment. For example, the user telecommunication activity records in a public mobile communication network are primarily used to charge the utilisation of the telecommunication services. However, by using appropriate procedures, potentially useful information could be extracted from such data. The data sources per categories are listed in Table 1.

\section{URBAN MOBILITY INDICATORS}

Indicator is a general term used to describe a parameter or a change of status within a certain system i.e. an on-going process. The indicators are used to present the conditions existing within a system in relation to the desired parameters, to indicate progress in line with the predefined objectives and to present the status of the system [39]. An indicator enables an efficient and simple monitoring of changes during a certain time period. The objective of the indicator is to represent mobility and trends in a compact, simple and clear way [40]. On the basis of the suitable (available) data from the segments of the transport system, economy, ecology, society and/or others, the urban mobility indicators are formed. In general, the urban mobility indicators are classified into five key groups. The transport indicators describe the transport-related categories (e.g. travel time and speed, trip matrices...) [41]. Economic indicators represent the impact of the individual economic components on the urban mobility (e.g. fuel price, parking fee, household income...) [39]. The social indicators represent the urban mobility through its social acceptancy (e.g. the number of accidents and fatalities...) [42]. The environmental indicators focus on the environment- and meteorology-related conditions (e.g. polluting emissions, noise) [43]. Additional indicators are those not included in the aforementioned groups (e.g. the existence of the regulatory frameworks, managing or mobility planning entities, urbanism, demography...) [13].

During the indicators development, it is necessary to select the ones meeting the following requirements $[11,13]$. An indicator has to be:

- comprehensive (has to impact transport, economic, social and environmental parameters);

- based on the high quality data (data collection and processing has to meet the scientific requirements in order to ensure accuracy and consistency);

- comparable (the data collection methodology has to be standardised in order to enable comparison);

- statistically and scientifically valid;

- temporally and geographically specified [39, 40];

- resistant to impacts;

- clear (it has to be useful for the decision makers and understandable for the general public) [44]; 
- adjusted to the specificities of the various locations, cultures, habits and institutions;

- cost-efficient (the costs of data collection and processing cannot be higher than the achieved benefits).

\subsection{Literature review}

The scientific literature demonstrates a detailed consideration of the urban mobility indicators as a topic of interest. Further in the text, an overview of the indicators from the most significant relevant literature is provided. Litman $[12,13]$ groups the indicators in the following categories: economic, social and ecological. The group of important economic indicators encompasses: the mobility per capita, the modal split, the average duration of traveling to work, the average speed of freight transportation, the costs of pollution per capita and the total transportation-related expenditures per capita. The category of social indicators includes the number of accidents and fatalities per capita, the overall satisfaction with the transport system, financial availability and the adjustment to the needs of the users with disabilities. The environmental indicators encompass: the energy consumption per capita per transport mode, the energy consumption per ton kilometre, the air pollution per capita, the land occupancy per capita, the air and noise pollution, the meteoric water drainage system coverage and others. The optional economic indicators involve the relative quality of the non-motorised transport and the number of public services and work opportunities available within a 10-minute walk or 20 minutes of travelling using some other transport mode. The optional social indicators include the share of persons walking or cycling longer than 15 minutes a day, the share of children walking and cycling to school, and others. The optional environmental indicators are the quality of life, water pollution, preservation of habitats, utilisation of the sustainable energy sources and the energy efficiency of buildings and facilities related to the transport system. Marletto and Mameli [45] define the indicator selection by setting up three groups of objectives, containing nine sub-objectives. The defined groups are: socially sustainable city, environmentally sustainable city and economically sustainable city. The final result is a set of 14 indicators. Toth-Szabo et al. [46] establish a framework for the development of the mobility indicators. In a wider sense, the indicators are initially grouped into three categories (economic, social and environmental). The economic indicators group includes efficiency, accessibility (the level of satisfaction of the businesses and public institution by the transport system, annual investments in the freight and passenger transportation), accessibility (satisfaction of the final users by the transport system for travelling to work and elsewhere). The social indicators define accessibility, safety and liveability. The group of the environmental indicators includes two sub-groups: emission and use of resources. For the needs of assessing the urban mobility in Lyon [47], a set of indicators is defined in order to create a relevant and simple system, connected to the existing statistical database. The indicators are grouped in four categories, related to the mobility, economy, society and environment. The mobility indicators include: the number of trips, travel time, travel purpose, modal split, daily average distance travelled by the motorised and non-motorised trips and average speed. The economy-related indicators are the annual infrastructural investments, parking fees, local tax, parking costs of the employees and household expenditure. Social indicators encompass the household income per unit of consumption, motorisation rate, the expenditure for public transportation, fuel costs, daily parking ticket costs, residents' parking ticket expenditure and fixed costs of a car allocated to urban mobility. The environmental indicators are the energy consumption and polluting emissions, travelling- and parking-related public space consumption, space occupied by the transport infrastructure. For the needs of the Sustainable Mobility Project 2.0 [4], the authors have defined a set of indicators for the urban mobility assessment. The objective of the defined indicators is to evaluate the mobility in cities. The indicators are distributed into four groups: global environment, quality of life, economic success and mobility system performance. A set of 19 indicators was determined. Every indicator is designated a value from 0-10 and the sum of the results gives the final value for the observed city. The data are collected by using one of the five defined methods: surveys, field measurements, usage of already existing data, geospatial analysis and modelling. Cianfrano et al. [48] define the following indicators for the purpose of the mobility assessment: the average transport network speed, the network speed indicator, the average vehicle speed, the vehicle speed indicator, the indicator of time spent within the network, the network delays indicator, the average travelling time, the average density of pollutants generated by transport, the average exposure to the transport-generated pollutants, the average exposure to the overall pollutants, the average duration of the exposure to the pollutants, the total polluting emissions. Norwood et al. [6] define mobility by using several key indicators which need to be included within every assessment. These are: the travel time, lost time, reliability of the system, the status of the transport system and travel costs. The optional indicators are divided into six groups: congestion-related, travel time, quantity of trips, modal split, transit time required and transit efficiency. Irman and Low [49] suggest a set of indicators grouped into the following categories: environment, society, economy and transport. The transport indicators are related to the non-motorised 
transport, car ownership, average travel time, traffic volume and vehicle status. The social indicators include urban density, space consumption, public transport availability, traffic related injuries and fatalities. The economic indicators are related to the fuel price, GDP per capita and space consumption in terms of the transport infrastructure. The environmental indicators involve greenhouse gas emissions, $\mathrm{CO}_{2}$ and $\mathrm{CH}_{4}, \mathrm{NO}_{2}$ and noise emissions. Barker et al. [50] analyse the sustainability of the transport system and mobility. The indicators are defined in terms of travel time i.e. congestion, transport-generated expenditure, casualties of traffic accidents, energy consumption and polluting emissions. The key indicator is the number of vehicle - kilometres. Costa et al. [7] define a set of measures for the sustainable urban mobility monitoring. The process of the indicator selection included several phases, where 465 mobility indicators were defined in the first phase. The second phase encompassed categorisation and grouping, thus resulting in a reduced list of 115 indicators, organised in categories and themes. The categories are transport and environment, infrastructure and transport technology, spatial planning and transport demands and socio-economic aspects of transport. The final list is narrowed down to 24 indicators. Within the Conduits project $[15,20]$, the authors Kaparis and Bell have defined a set of indicators intended for the traffic management and the Intelligent Transport Systems. The group of indicators called "Traffic Efficiency" deals with mobility defined by 14 indicators: the average duration of a road trip to the appropriate point of interest, the average duration of trips to the appropriate point of interest carried out by using the public passenger transport system, the capacity/supply of the public transport system, the time required to switch between transport modes, the average distance between different transport modes, the time required to access the station, the average duration of a search for a parking place, the average duration of the daily trips, the average distance covered by the daily trips, the total length of the road network, the coverage of the road network by ITS services, the modal split, the share of non-motorised trips in daily commuting and the length of the transport network intended for non-motorised trips. EYGM [51] defines the urban mobility indicators as a set of basic parameters with a potential to help the local administration with a proactive interaction with the shareholders of the mobility ecosystem. The framework consists of three indicator groups: city structural factors, mobility infrastructure and demographics. During the Civitas project and within the tool for the integrated mobility planning, Stantchev and Rye [52] have defined six groups of the key personal mobility indicators related to public

Table 2 - An overview of the transport indicators [4, 6, 7, 15, 20, 47-49]

\begin{tabular}{|c|c|c|c|}
\hline Transport indicators & Unit & Transport indicators & Unit \\
\hline Average distance covered by daily trips & $\mathrm{km}$ & Quantity of trips & vehicle/h \\
\hline Average daily trip duration per person & $\mathrm{h}$ & Number of trips & number \\
\hline Average trip duration per kilometre & $\mathrm{h}$ & Travel time & $\mathrm{h}$ \\
\hline Average trip duration per vehicle & $\mathrm{h}$ & Travel purpose & $\%$ \\
\hline Total number of passenger and ton kilometres & $\mathrm{pkm} / \mathrm{tkm}$ & $\begin{array}{l}\text { Average travel time using public } \\
\text { transport system to the desired point of } \\
\text { interest }\end{array}$ & $\mathrm{h}$ \\
\hline Reliability factor & $0-1$ & $\begin{array}{l}\text { Capacity/supply of public passenger } \\
\text { transport system }\end{array}$ & $\begin{array}{l}\text { number of } \\
\text { passenger } \\
\text { seats }\end{array}$ \\
\hline $\begin{array}{l}\text { Average travel time using road network to the } \\
\text { desired point of interest }\end{array}$ & $\mathrm{h}$ & $\begin{array}{l}\text { Time required to switch between } \\
\text { transport modes }\end{array}$ & $\mathrm{h}$ \\
\hline Average vehicle speed & $\mathrm{km} / \mathrm{h}$ & $\begin{array}{l}\text { Average distance between transport } \\
\text { modes }\end{array}$ & $\mathrm{km}$ \\
\hline Average freight transport speed & $\mathrm{km} / \mathrm{h}$ & Station access time & $\mathrm{h}$ \\
\hline Road network length & $\mathrm{km}$ & Public transport services per inhabitant & $\begin{array}{l}\text { trips per } \\
\text { inhabitant }\end{array}$ \\
\hline $\begin{array}{l}\text { Length of the transport network intended for } \\
\text { non-motorised trips. }\end{array}$ & $\mathrm{km}$ & Modal split & $\%$ \\
\hline Coverage of the road network with ITS services & $\%$ & $\begin{array}{l}\text { Average duration of a search for a } \\
\text { parking place }\end{array}$ & $\mathrm{h}$ \\
\hline Traffic volume (Passenger Car Equivalent) & PCE & Congestions in the transport system & $\mathrm{h}$ \\
\hline Road capacity & vehicle/h & Delays in the transport system & $\mathrm{h}$ \\
\hline Quantity of trips vehicle/kilometres & vehicle $/ \mathrm{km}$ & & \\
\hline
\end{tabular}


Table 3 - An overview of the economic indicators [4, 12, $13,46,47,49,53]$

\begin{tabular}{||l|c||}
\hline \multicolumn{1}{|c|}{ Economic indicators } & Unit \\
\hline \hline Public transport single ticket price & HRK \\
\hline Fuel price (per litre) & HRK \\
\hline Price of the daily parking ticket & HRK \\
\hline Cost of resident parking & HRK \\
\hline $\begin{array}{l}\text { Cost of parking for the employees of the } \\
\text { companies }\end{array}$ & HRK \\
\hline Cost of public bike sharing system usage & HRK \\
\hline Cost of public car sharing system usage & HRK \\
\hline $\begin{array}{l}\text { Fixed costs of a car (allocated to the urban } \\
\text { mobility) }\end{array}$ & HRK \\
\hline Pollution costs per inhabitant & HRK \\
\hline Total transport costs per inhabitant & HRK \\
\hline $\begin{array}{l}\text { The number of public services and work } \\
\text { opportunities within a 10-minute reach by } \\
\text { walking or 20 minutes by transportation }\end{array}$ & number \\
\hline Total household expenditure & HRK \\
\hline Household income per unit of consumption & HRK \\
\hline $\begin{array}{l}\text { Average mobility - related expenditure of } \\
\text { households, companies and city management }\end{array}$ & HRK \\
\hline $\begin{array}{l}\text { The share of companies and public institutions } \\
\text { satisfied with the financial aspects of mobility }\end{array}$ & HRK \\
\hline $\begin{array}{l}\text { Annual investments to the freight and } \\
\text { passenger transport }\end{array}$ & HRK \\
\hline Annual infrastructure investments & HRK \\
\hline Total costs generated by transport & \\
\hline GDP & HRK \\
\hline
\end{tabular}

transport, accessibility, active travelling, parking and car and bicycle sharing, results and environmental impacts.

\subsection{An overview of indicators per categories}

The mobility indicators available in the literature and listed in the previous chapter could be grouped according to their main domains.

Therefore, the mobility indicators could be organised as sets of transport, economic, environmental, social and other indicators. The transport indicators present the mobility through the categories related to the transport aspect and reflect the impact of those components on mobility. The transport indicators with the relevant units of measure are shown in Table 2.

The economic indicators describe mobility through the categories related to the economic aspect and reflect the impact of the individual economic components on mobility. The social indicators present mobility through its social acceptancy. Economic and social indicators with the relevant units of measure are shown in Tables 3 and 4.

The environmental indicators describe mobility by using the categories related to the environment, meteorological conditions, etc. The other, remaining indicators are those which cannot be classified in any of the aforementioned categories (e.g. the existence of the regulatory frameworks, entities for mobility management and planning, urbanism, demographics...). The environmental and other indicators with the relevant units of measure are presented in Tables 5 and 6 .

The next step in the urban mobility assessment is the development of the urban mobility index, based on the urban mobility data and indicators.

Table 4 - An overview of the social indicators [4, 12, 13, 46, 47, 49]

\begin{tabular}{||l|c||}
\hline \multicolumn{1}{|c|}{ Social indicators } & Unit \\
\hline \hline Number of accidents & number \\
\hline Number of persons injured & number \\
\hline Number of persons killed & $\%$ \\
\hline Adjustment of the transport system to the specific user groups & $\%$ \\
\hline Overall satisfaction with the transport system & $\%$ \\
\hline Adjustment to persons with special needs & $\%$ \\
\hline Share of persons walking or cycling longer than 15 minutes a day & $\%$ \\
\hline Share of children walking or cycling to school & $\%$ \\
\hline Communication cohesion & $\%$ \\
\hline Perception of security & $\%$ \\
\hline The share of users feeling safe considering the traffic incidents & $\%$ \\
\hline Satisfaction with the transport - related public space & \% \\
\hline Access to mobility services & no/inhabitant/km \\
\hline Number of traffic accidents in the transport system per inhabitant/kilometre & $\%$ \\
\hline
\end{tabular}


Table 5 - An overview of the environmental indicators [4, 6, 7, 12, 13, 15, 20, 45-47, 48, 49]

\begin{tabular}{||l|c|l|c||}
\hline \multicolumn{1}{|c|}{ Environmental indicators } & Unit & \multicolumn{1}{c|}{ Environmental indicators } & Unit \\
\hline \hline Noise & $\mathrm{dB}$ & Waste generated by transport activities & $\mathrm{t}$ \\
\hline Preenhouse gas emission & $\mathrm{g} / \mathrm{km}$ & Transport-related land consumption per inhabitant & $\%$ \\
\hline Energy consumption & $\mathrm{g} / \mathrm{km}$ & Consumption of public space for mobility needs & $\%$ \\
\hline Utilisation of the sustainable energy sources & $\mathrm{kWh}$ & Consumption of public space for parking needs & $\%$ \\
\hline $\begin{array}{l}\text { Share of the renewable energy in the total } \\
\text { energy consumed by the transport system }\end{array}$ & $\%$ & $\begin{array}{l}\text { Consumption of public space by transport } \\
\text { infrastructure }\end{array}$ & $\%$ \\
\hline $\begin{array}{l}\text { Energy consumption per capita by different } \\
\text { modes }\end{array}$ & $\mathrm{kWh}$ & Average exposure to transport - related pollutants & $\%$ \\
\hline Energy consumption per ton - kilometre & $\mathrm{kWh} / \mathrm{tkm}$ & Average exposure to overall pollutants & $\%$ \\
\hline $\begin{array}{l}\text { Number of days with air pollutants exceeding } \\
\text { the limitations }\end{array}$ & $\begin{array}{c}\mathrm{number} \\
\text { of days }\end{array}$ & Impact of car usage & $\begin{array}{c}\text { value } \\
(1-5)\end{array}$ \\
\hline Environmental investments & $\mathrm{HRK}$ & Average duration of exposure to pollutants & $\mathrm{h}$ \\
\hline $\begin{array}{l}\text { Share of population unsatisfied with the } \\
\text { transport-related emission and noise levels }\end{array}$ & $\%$ & Meteorological conditions & $\begin{array}{c}\text { value } \\
(1-5)\end{array}$ \\
\hline $\begin{array}{l}\text { Share of population that considers the trans- } \\
\text { port - related consumption of land to be } \\
\text { appropriate }\end{array}$ & $\%$ & $\begin{array}{l}\text { Energy efficiency of supporting buildings and } \\
\text { facilities in the transport system }\end{array}$ & $\begin{array}{c}\text { value } \\
(1-5)\end{array}$ \\
\hline $\begin{array}{l}\text { Share of population that considers the sustain- } \\
\text { able energy sources available }\end{array}$ & $\%$ & & \\
\hline
\end{tabular}

Table 6 - An overview of other indicators $[4,6,7,12,13$, $15,20,45-47,48,49]$

\begin{tabular}{|c|c|}
\hline Other indicators & Unit \\
\hline Motorisation rate (2 or 4-wheelers) & $\begin{array}{l}\text { no. vehicles } / 1,000 \\
\text { inhabitants }\end{array}$ \\
\hline Mobile phone penetration & $\%$ \\
\hline Alternatives to mobility & value (1-5) \\
\hline Ease of movement & value (1-5) \\
\hline $\begin{array}{l}\text { Public and private services available } \\
\text { via phone or computer }\end{array}$ & value (1-5) \\
\hline $\begin{array}{l}\text { Number of motorised vehicles per } \\
\mathrm{km}^{2}\end{array}$ & vehicle $/ \mathrm{km}^{2}$ \\
\hline Traffic management system & YES/NO \\
\hline Environmental monitoring system & YES/NO \\
\hline Trip reduction plan & YES/NO \\
\hline City centre accessibility & value $(1-5)$ \\
\hline $\begin{array}{l}\text { Accessibility of the main services } \\
\text { and shops by different transport } \\
\text { modes }\end{array}$ & value (1-5) \\
\hline Urban planning & YES/NO \\
\hline Age & year \\
\hline Education & value (1-5) \\
\hline Economic status & value $(1-5)$ \\
\hline Vehicle ownership & $\%$ \\
\hline Driving licence possession & $\%$ \\
\hline
\end{tabular}

\section{URBAN MOBILITY INDICES}

The urban mobility index could be defined as a result of the relational data and/or mobility indicators fusion, with an aim to assess mobility. The indices are used to reduce the complexity and scope of data and indicators to be included in the urban mobility assessment. The advantages of the index application lies in the possibility to synthesize a significant amount of information in a single scalar. Index is used for the status assessment of the complex system as a whole, not on the level of the individual components. Also, indices obtained by the same methodology are comparable. However, the application of indices also has some deficiencies. Since the result is a single number, an index does not provide insight into the changing elements i.e. it is not equally resilient to the changes of individual components. Therefore, an index can disguise the correct information and its robustness can be limited by the different spatial and temporal factors [44].

The scientific literature provides information on several mobility indices representing mobility by a single number generated from data, indicators and/or other indices through an appropriate mathematical model. The first widely spread urban mobility index was defined by Frei and it is called a sampling mobility index (SMI) [54]. The sampling mobility index is represented by Relation 1. Frei has formed a set of indicators and indices intended for the measurement of the mobility 
level in small and medium-sized urban surroundings. The mobility indicators are defined through the following criteria: the sidewalk width, the free walking pass, the vertical and horizontal signalling, the safety belt use, the respect for traffic lights, the pedestrian traffic lights, the more than one person per vehicle criterion and the cycling lane availability. For each of the criteria, an indicator was defined and then synthesized into seven indices, one for every criterion. This approach enables the normalisation of different parameters i.e. the reduction of all criteria to a single dimension. These seven indices are integrated in one index called the sampling mobility index. The data used in the calculation are obtained by the field analysis or through surveys. The index represents a sum of values of the seven included indices:

$S M I=\sum(S W I+F W P I+V H S I+S B U I+R T L I+P T L I+M O P V I+I C)$

where: $S W I$ is Sidewalk Width Index, FWPI is Free Walking Pass Index, VHSI is Vertical and Horizontal Signalling Index, SBUI is Safety Belt Use Index, RTLI is Respect for Traffic Lights Index, PTLI is Pedestrian Traffic Lights Index, MOPVI is More than One Person per Vehicle Index, IC is Cycling lane availability Index.

The highest possible value of the index is 700 points and the lowest is zero. The total span is divided into five categories, where the first one, from 0-140 points, denotes the worst result (red) and from 560 to 700 points the best one (green) [43].

The Travel Time Index TTI (Equation 2), identified by the authors [55] is used for measuring the congestion differences between metropolitan areas and is related to the traffic flow speed. The Travel Time Index is calculated as a quotient of the time required for travelling during the congestion (Congested Travel Time) and the time needed to pass the same section without congestion (Free Flow Travel Time).

$T T I=\frac{\text { Congested Travel Time }}{\text { Free Flow Travel Time }}$

To benchmark smart transport cities [56], a composite scoring system (index) was developed to measure the Smartness Index (SI) of a city's transportation system (Equation 3). SI utilizes the scores of each component of the smartness indicators matrix (consists of 21 indicators) to calculate a composite score using Equation 3.

$S I=\frac{\sum_{j=1}^{J} \sum_{i=1}^{I} S_{i j}}{\sum_{j=1}^{J} I_{j}} \cdot 100 \%$

where $S I$ represents the smartness index, $S_{i j}$ is the smartness score for indicator $i$ in each sub-system $j$, $J$ is the total number of sub-systems, and $I_{j}$ is the total number of indicators in each sub-system. Results showed that London was the smartest among the 26 studied cities for its transportation system $(S I=67.1 \%)$, followed by Seattle $(S I=59.2 \%)$, Sydney $(S I=57.2 \%)$, New York $(S I=56.9 \%)$ and Melbourne $(S I=56.5 \%)$. The top cities in smart private transport services were Seattle $(S I=56.6 \%)$, New York $(S I=54.8 \%)$, and Paris ( $S I=54.8 \%)$, whereas London $(S I=88.4 \%)$, Singapore $(S I=71.7 \%)$ and Paris $(S I=63.4 \%)$ ranked highest in terms of public transport.

Shared Mobility City Index is an example of an index generated as a sum of the assessment result values of 11 individual indicators, assessing mobility in three categories (general information and demographics, mobility, vision and objectives). The index is intended for the decision makers on the level of the city administration in the cases when the new mobility-related services are being introduced. The index also enables an insight into the needs and the readiness of a certain environment to implement the public vehicle sharing systems (a car sharing system) [57].

The Urban Mobility Index, developed by the Imperial College in London within the Conduits project, represents a parameter denoting the mobility status within the intelligent transport system, calculated by the mathematical model (Equation 4) [20].

$$
\begin{aligned}
& I_{m o b}= W_{P V} \cdot \frac{1}{\left|R_{P V}\right|} \sum_{r \in R P V}^{\left|R_{P V}\right|} \frac{A T T_{P V}^{r}}{D_{r}}+ \\
& W_{P T} \cdot \frac{1}{\left|R_{P T}\right|} \sum_{r \in R P T}^{|R P T|} \frac{A T T_{P T}^{r}}{D_{r}}
\end{aligned}
$$

where:

$I_{m o b}$ is the mobility index;

$r$ is the route (trip matrix) between the selected $R_{P V}$ (personal vehicle routes) and $R_{P T}$ (public transport routes);

$A T T_{P V}^{r}$ is the average travel time for route $r$ using personal transport modes;

$A T T_{P T}^{r}$ is the average travel time for route $r$ using public transport;

$D_{r}$ is the length of route $r$;

$W_{P V}$ represents the weighting factors for the travel time using personal vehicle;

$W_{P T}$ represents the weighting factors for the travel time using public transport.

The weighting factors are determined by the Delfi method [46]. In the initial circle of the Delfi method, an assessment of the relative relevance of the individual indicators is carried out, for each indicator individually. Each expert assigns a value from 0 to 1 to the indicator. In the second circle, the information about the relations between the individual indicators included in the index are being collected and the answers from the previous circles are being verified. The final result is a set of the weighting factors from 0 to 1 which are then integrated in the model. The mobility index $I_{m o b}$ is expressed as travel time per kilometre. 
The authors have upgraded the index by the inclusion of the route relevance factor in the model, as presented in Equation 5 [15]:

$$
\begin{aligned}
& I_{m o b}= W_{P V} \cdot \frac{1}{\left|R_{P V}\right|} \cdot w_{r} \cdot \sum_{r \in R P V}^{|R P V|} \frac{A T T_{P V}^{r}}{D_{r}}+ \\
& W_{P T} \cdot \frac{1}{\left|R_{P T}\right|} \cdot w_{r} \cdot \sum_{r \in R P T}^{|R P T|} \frac{A T T_{P T}^{r}}{D_{r}}
\end{aligned}
$$

where $w_{r}$ represents the weighting factors for the relevant route.

In relation to the previous iteration, the new element is the weighting factor for the relevant route $\left(w_{r}\right)$ also calculated by the Delphi method, while the other elements and the methodology remained unchanged. The conclusion is that there is no generally accepted index for the urban mobility assessment. The existing urban mobility indicators and indices are mostly developed for the specific cities or urban areas, taking into consideration the local specificities, thus territorially limiting their application. Regardless of the sig nificant number of the defined mobility indicators, a limited number of them are used to develop an urban mobility index. Also, the selection of the urban mobility indicators is mostly related to the data availability i.e. depends on an existence of a specific data source, hindering the objective and comparable assessment of the mobility within the urban agglomerations where such data or sources do not exist. Finally, the urban mobility assessment usually uses the conventional data sources, while the potential of the "new" data sources remains insufficiently exploited.

\section{CONCLUSION}

Urban mobility is exposed to the negative impacts of the global trends, consequently leading to the growth of the external costs associated with the transport system and a decrease in the quality of the transport services. For determining the mobility status, a methodology is used integrating different metrics and explicitly applying a multidimensional approach. A large number of various types of data expressed by the indicators, requires an application of integrated indices for the presentation of the unique mobility status. These encompass different indicators and synthesize them to a single parameter. The indices are used to measure trends and monitor progress, being easy to use and interpret. The result of the performance index is a single unique assessment of the personal mobility within the urban transport, gained from the data provided by the intelligent transport systems.

Previous research has shown a detailed elaboration of the indicator sets usable for the purpose of the mobility assessment, which sometimes include more than a thousand various parameters. In order to ensure the simplicity of the calculation, the number of indicators is eventually reduced to ten or more (not more than thirty). In terms of determining the unique and objective mobility assessment result, the future research should focus on the mobility assessment by using indicators and indices mostly based on realistic measurements. The replacement of these crucial sources can be found by utilizing the additional modern information and communication data sources, including the intelligent transport systems. The future research should also be directed towards the development of the index with a clearly defined relations (weight factors) between the indicators and other indices, by applying novel methodology, (for example data science) rather than pure Delphi. Further research will also address the possibility of creating a "universal" urban mobility index, that will be applicable to various urban environments. It will overcome the common problem of forming the indicators based on available data by selecting data sources that do exist in all urban environments (for example anonymized big data sets from mobile telecommunication network).

\section{Dr. sc. KREŠIMIR VIDOVIĆ ${ }^{1}$}

E-mail: kresimir.vidovic@ericsson.com

Doc. dr. Sc. MARKO ŠOŠTARIĆ ${ }^{2}$

E-mail: marko.sostaric@fpz.hr

Dr. sc. DAMIR BUDIMIR ${ }^{2}$

E-mail: damir.budimir@fpz.hr

${ }^{1}$ Ericsson Nikola Tesla

Krapinska 45, 10000 Zagreb, Hrvatska

2 Fakultet prometnih znanosti, Sveučilište u Zagrebu Vukelićeva 4, 10000 Zagreb, Hrvatska

\section{PREGLED POKAZATELJA I INDEKSA U FUNKCIJ PROCJENE URBANE MOBILNOSTI}

\section{SAŽETAK}

Na mobilnost u gradovima utječu globalni trendovi koji rezultiraju generiranjem sve veće prijevozne potražnje ljudi i dobara unutar urbanog područja. Kako bi se općenito poboljšalo razumijevanje urbane mobilnosti, ocijenile usluge iz domene urbane mobilnosti $\mathrm{i}$ kvantificirala ukupna učinkovitost prometnog sustava, urbanu mobilnost potrebno je procijeniti. Prilikom ocjenjivanja mobilnosti koristi se metodologija koja integrira različite metrike i eksplicitno uzima u obzir više-dimenzijski pristup. Obzirom da znanstvena zajednica ne definira nedvosmisleno urbanu mobilnost, dio ovog rada posvećen je analizi definicije urbane mobilnosti. Ovaj korak omogućuje bolje razumijevanje urbane mobilnosti općenito, kao i razumijevanje procesa procjene urbane mobilnosti. Za procjenu se obično koristi troslojni pristup koji uključuje podatke o mobilnosti u gradu, pokazatelje i indekse. Cilj ovog rada bio je provesti opsežna istraživanja kako bi se sintetizirali, definirali i organizirali elementi tih slojeva. Postojeći pokazatelji i indeksi urbane mobilnosti uglavnom su ciljano 
razvijani za određene gradove ili urbana područja, uzimajući u obzir lokalne specifičnosti, tako da nisu primjenjivi u drugim gradovima. Također, izbor pokazatelja urbane mobilnosti uglavnom je povezan s postojanjem izvora podataka, što ograničava objektivnu i usporedivu procjenu mobilnosti gradova u kojima takvi podaci ne postoje.

\section{KLJUČNE RIJEČI}

promet; urbana mobilnost; procjena; ekologija; društvo; ekonomski pokazatelji; indeksi; inteligentni transportni sustavi;

\section{REFERENCES}

[1] Kuhlke O. Mobilities, Networks, Geographies. Prof Geogr. 2008 Aug;60(3): 429-30. Available from: doi:10.1080/00330120802115391

[2] Brčić D, Ševrović M. Logistika prijevoza putnika. Zagreb: Fakultet pormetnih znanosti Sveučilišta u Zagrebu; 2012. 139 p.

[3] Hanson S, Giuliano G. The Geography of urban transportation. London, UK: The Guliford Press; 2004.

[4] Gillis D, Semanjski I, Lauwers D. How to monitor sustainable mobility in cities? Literature review in the frame of creating a set of sustainable mobility indicators. Sustain. 2016;8(1): 1-30.

[5] Amaral RR, Šemanjski I, Gautama S, Aghezzaf EH. Urban mobility and city logistics - Trends and case study. Promet - Traffic - Traffico. 2018;30(5): 613-22.

[6] Casey J, Norwood JL, editors. Key transportation indicators: Summary of a workshop. Washington, D.C.: National Academy Press; 2002. 41 p. Available from: http://www.nap.edu/catalog/10404

[7] Costa MS, Silva ANR, Ramos RAR. Sustainable urban mobility: a comparative study and the basis for a management system in Brazil and Portugal. Urban Transp XI Urban Transp Environ 21 ${ }^{\text {th }}$ century. 2005;77: 323-32.

[8] Brčić D, Šoštarić M. Parkiranje i garaže. Zagreb: Fakultet prometnih znanosti Sveučilišta u Zagrebu; 2012.

[9] Rashidy EL, Ahmed R, Muller G, EL Rashidy, Rawia Ahmed and Grant Muller S. A network mobility indicator using a fuzzy logic approach. TRB $93^{\text {rd }}$ Annu Meet Compend Pap Transp Res Board. 2014;44: 1-14.

[10] Gudmundsson H. Making concepts matter: sustainable mobility and indicator systems in transport policy. Int Soc Sci J. 2003;55(176): 199-217. Available from: http://dx.doi.org/10.1111/j.14682451.2003.05502003.x

[11] Litman T. Developing Indicators for Comprehensive and Sustainable Transport Planning. Transp Res Rec. 2007;2017(1): 10-15.

[12] Litman T. Well Measured - Developing Indicators for Sustainable and Livable Transport Planning. Victoria, BC, CA: Victoria Transport Policy Institute; 2016.

[13] Litman T. Measuring transportation: Traffic, mobility and accessibility. ITE J.-Inst. Transp. Eng. 2003;73(10): 28-32.

[14] Litman T. Evaluating Accessibility for Transport Planning - Measuring People's Ability to Reach Desired Goods and Activities. Victoria, BC, CA: Victoria Transport Policy Institute; 2019. Available from: https://vtpi.org/access.pdf
[15] Kaparias I, Eden N, Tsakarestos A, Gal-Tzur A, Gerstenberger M, Hoadley S, et al. Development and Application of an Evaluation Framework for Urban Traffic Management and Intelligent Transport Systems. Procedia - Soc Behav Sci. 2012;48: 3102-12.

[16] Abramović B, Šipuš D. Prijedlog za poboljšanje mobilnosti na području Grada Siska. Željeznice 21. 2015;14(4): 93-8.

[17] Vidović K, Mandžuka S, Brčić D. Estimation of urban mobility using public mobile network. In: Muštra M, Vitas D, Zovko-Cihlar B, editors: Proceedings of the $59^{\text {th }}$ International Symposium ELMAR-2017, 18-20 September 2017, Zadar, Croatia. Zagreb, Croatia: Faculty of Electrical Engineering and Computing; 2017.

[18] Zelenika R. Metodologija i tehnologija izrade znanstvenog i stručnog djela IV. Rijeka: Ekonomski fakultet Sveučilišta u Rijeci; 2000.

[19] Mandžuka S, Ivanjko E, Vujić M, Škorput P, Gregurić M. The Use of Cooperative ITS in Urban Traffic Management. Intell Transp Syst Technol Appl. 2015; 272-88.

[20] Kaparias I, Bell MGH. Key Performance Indicators for Traffic Management and Intelligent Transport Systems. London; 2011.

[21] Yousaf M. Shah. Developing Key Performance Indicators to assess Urban Transportation Systems. McGill University; 2012.

[22] González MC, Hidalgo CA, Barabási A-L. Understanding individual human mobility patterns. Nature. 2008;453(June): 779-82. Available from: http:// barabasi.com/f/250.pdf

[23] Wu J, Wu T. Sustainability Indicators and Indices. Handbook of Sustainable Management. London, UK: Imperial College Press; 2012. p. 65-86.

[24] Zhang D, Huang J, Li Y, Zhang F, Xu C, He T. Exploring human mobility with multi-source data at extremely large metropolitan scales. In: Proceedings of the $20^{\text {th }}$ annual international conference on Mobile computing and networking - MobiCom '14, New York, New York, USA. ACM Press; 2014. p. 201-12. Available from: http:// dl.acm.org/citation.cfm?doid=2639108.2639116

[25] Lopes J, Bento J, Huang E, Antoniou C, Ben-Akiva M. Traffic and Mobility Data Collection for Real-Time Applications. $13^{\text {th }}$ International IEEE Conference on Intelligent Transportation Systems, 19-22 Sept. 2010, Funchal, Portugal. IEEE; 2010. p. 216-223. Available from: http://ieeexplore.ieee.org/xpls/abs_all.jsp?arnumber $=5625282$

[26] Chen C, Ma J, Susilo Y, Liu Y, Wang M. The promises of big data and small data for travel behavior (aka human mobility) analysis. Transp Res Part C. 2016;68: 285-299.

[27] Stančić A, Grgurević I, Kavran Z. Integration of Transport-relevant Data within Image Record of the Surveillance System. Promet - Traffic \& Transportation. 2016;28(5): 517-27.

[28] Prabha R, Kabadi MG. Overview of Data Collection Methods for Intelligent Transportation Systems. Int J Eng Sci. 2016;5(3): 16-20.

[29] Wang H, Calabrese F, Di Lorenzo G, Ratti C. Transportation mode inference from anonymized and aggregated mobile phone call detail records. $13^{\text {th }}$ International IEEE Conference on Intelligent Transportation Systems, 19-22 Sept. 2010, Funchal, Portugal. IEEE; 2010. p. 318-23. Available from: http://ieeexplore. 
ieee.org/stamp/stamp.jsp?tp $=$ \&arnumber $=5625188$

[30] Frias-Martinez V, Soguero C, Frias-Martinez E. Estimation of urban commuting patterns using cellphone network data. Proceedings of the ACM SIGKDD International Workshop on Urban Computing - UrbComp'12, 12-16 August 2012, Beijing, China. 2012; p. 9-16.

[31] Calabrese F, Diao M, Lorenzo G Di, Ferreira J, Ratti C. Understanding individual mobility patterns from urban sensing data: A mobile phone trace example. Transp Res Part C. 2013;26: 301-313.

[32] Chen C, Bian L, Ma J. From traces to trajectories: How well can we guess activity locations from mobile phone traces? Transp Res Part C Emerg Technol. 2014;46: 326-37. Available from: doi:10.1016/j.trc.2014.07.001

[33] Çolak S, Alexander LP, Alvim BG, Mehndiretta SR, Gonzalez MC. Analyzing Cell Phone Location Data for Urban Travel: Current Methods, Limitations and Opportunities. TRB 2015 Annu Meet. 2015; p. 1-17.

[34] Vidović K, Mandžuka S, Brčić D. ANFIS Based Expert Systems Prototype Development for Estimation of Urban Mobility. In: Proceedings of $60^{\text {th }}$ International Symposium ELMAR-2018, 16-19 September 2018, Zadar, Croatia. Zagreb, Croatia: Faculty of Electrical Engineering and Computing; 2018. p. 47-50.

[35] Mandžuka B, Brčić D, Škorput P. Primjena multimodalnih putnih vodiča za gradska i međugradska putovanja. In: $34^{\text {th }}$ Conference on Transportation Systems with International Participation „Automation in Transportation“, 5-9 November 2014, Dubrovnik, Croatia; 2014.

[36] Mandžuka S, Brčić D, Škorput P. ITS in the function of sustainable urban mobility. In: $22^{\text {nd }}$ Iternational Symposium on Electronic in Transporrt - ISEP 2014. Ljubljana, Slovenia; 2014.

[37] Vidović K, Mandžuka S, Brčić D. Estimation of Urban Mobility using Public Mobile Network. In: Muštra M, Vitas D, Zovko-Cihlar B, editors: Proceedings of the 59th International Symposium ELMAR-2017, 18-20 September 2017, Zadar, Croatia. Zagreb, Croatia: Faculty of Electrical Engineering and Computing; 2017. p. 21-4. Available from: http://bib.irb.hr/prikazi-rad?rad $=892828$

[38] Mamdoohi AR, Zavareh MF, Hydén C, Nordfjærn T. Comparative analysis of safety performance indicators based on inductive loop detector data. Promet - Traffic - Traffico. 2014;26(2): 139-49.

[39] Marsden Sotirios GT. Improved indicators for sustainable transport and planning: Measuring wider economic benefits of transport - A case study in good practice for indicator selection. Leeds, UK: Institute for Transport Studies University of Leeds; 2008.

[40] Marsden G, Snell C. The role of indicators, targets and monitoring in decision-support for transport. Eur $J$ Transp Infrastruct Res. 2009;9(3): 219-36.

[41] Alberti M. Measuring urban sustainability. Vol. 16, Environmental Impact Assessment Review; 1996. p. 381-424.

[42] Anastasi G, Antonelli M, Bechini A, Brienza S, D’Andrea
E. Urban and social sensing for sustainable mobility in smart cities. In: Proceedings of Sustainable Internet and ICT for Sustainability (SustainIT). Palermo, Italija; 2013.

[43] Huang L, Jianguo W, Yan L. Defining and measuring urban sustainability: A review of indicator. Landsc Ecol. 2015;30: 1175-93.

[44] Zietsman J, Rilett LR. Sustainable Transportation: Conceptualization and Performance Measures. Vol. 7. Austin, USA: Texas Transportation Institute; 2002. 163 p. Available from: http://swutc.tamu.edu/publications/technicalreports/167403-1.pdf

[45] Mameli F, Marletto G. A selection of indicators for monitoring sustainable urban mobility policies. Trasp Ambient e Territ La Ric di un nuovo equilibrio, Milano; 2009.

[46] Toth-Szabo Z, Várhelyi A. Indicator Framework for Measuring Sustainability of Transport in the City. Procedia - Soc Behav Sci. 2012;48: 2035-47.

[47] Nicolas JP, Pochet P, Poimboeuf H. Towards sustainable mobility indicators: Application to the Lyons conurbation. Transp Policy. 2003;10(3): 197-208.

[48] Cianfano M, Gentile G, Nussio F, Tuffanelli G, Rossi P, Vergini R, Terenzi G. Transport and Mobility Indicators Based on Traffic Measures - Good Practices Guidebook; 2008.

[49] Imran M, Low N. Time to Change the Old Paradigm: Promoting Sustainable Urban Transport. World Transp Policy Pract. 2003;9(2): 32-9.

[50] Barker W. Can a Sustainable Transportation System Be Developed for San Antonio, Texas. Transp Res Rec J Transp Res Board. 2005 Jan;1924: 120-8. Available from: doi:10.3141/1924-16

[51] EYGM. Urban mobility redifined; 2015. Available from: http://www.ey.com/Publication/vwLUAssets/EY-urban-mobility-redefined/\$FILE/EY-urban-mobility-redefined.pdf

[52] Stantchev D, Rye T. Findings and Recommendations from CIVITAS CAPITAL Advisory Groups Data and Statistics. Edinburgh; 2015.

[53] Ševrović M, Brčić D, Kos G. Transportation Costs and Subsidy Distribution Model for Urban and Suburban Public Passenger Transport. Promet - Traffic \& Transportation. 2015;27(1): 23-33.

[54] Frei F. Sampling mobility index: Case study in Assis-Brazil. Transp Res Part A Policy Pract. 2006;40(9): 792-9.

[55] Cortright J. Measuring Urban Transportation Performance. Chicago: Impresa; 2010.

[56] Kumar A, Chor H, Haque M, Yuen B. A methodological framework for benchmarking smart transport cities. Cities. 2014;37: 47-56. Available from: doi:10.1016/j. cities.2013.11.004

[57] Murr S, Phillips S. The Proposal of a Shared Mobility City Index to Support Investment Decision Making for Carsharing. World Acad Sci Eng Technol Int J Soc Behav Educ Econ Bus Ind Eng. 2016;10(2): 610-7. 